\title{
MONITORING MERKURI PADA KOSMETIKA DENGAN STANDAR UJI ASEAN DOCUMENT ACM THA 05
}

\author{
(MONITORING OF MERCURY IN THE COSMETICS USING \\ TEST STANDARD ASEAN DOCUMENT ACM 05 THA)
}

\author{
Irma Rumondang dan Annisa Lestari \\ Balai Besar Kimia dan Kemasan, Kementerian Perindustrian RI \\ Jl. Balai Kimia I Pekayon, Pasar Rebo, Jakarta Timur \\ E-mail : rundong_cm@yahoo.com
}

Received : 2 Januari 2012; revised : 30 Januari 2012; accepted :11 April 2012

\begin{abstract}
ABSTRAK
Peraturan Menteri Kesehatan No. 445/Menkes/Per/V/1998 menginstruksikan untuk melarang penggunaan merkuri pada kosmetika. SNI 16-4954-1998 hanya menyebutkan bahwa secara kualitatif kandungan merkuri dengan metode uji yang telah divalidasi, tanpa menjabarkan metode uji yang valid. Penelitian ini bertujuan untuk menganalisa kandungan merkuri pada kosmetik di pasaran yang diracik menggunakan metode ACM THA 05 revisi 1. Untuk memastikan bahwa hasil analisa kosmetik dapat dipertanggung jawabkan maka terlebih dahulu dilakukan verifikasi terhadap metode uji tersebut dengan parameter presisi, akurasi, linearitas, dan limit deteksi dimana hasil verifikasi menunjukkan nilai yang memenuhi batasan yang dipersyaratkan. Dari hasil analisa terhadap kosmetika yang ada di pasaran menunjukkan krim wajah dan sabun mengadung merkuri dalam level konsentrasi persen.
\end{abstract}

Kata kunci : Merkuri, Kosmetik, Verifikasi.

\begin{abstract}
Regulation of the Minister of Health No.445/Menkes/Per/V/1998 prohibit the use of mercury in cosmetics. SNI 164954-1998 describe the qualitative content of mercury with the approved test method, without discription of rightfull test methods. Purpose of the reseach was aimed to analyze the content of mercury in cosmetics formulated on the market by using method of the ACM 05 revision THA 1. To ensure that The result of cosmetic analysis can be justified then be verified prior to the assay method with the parameters of precision, accuracy, linearity, and detection limits in which the results of verification value has been meets with the standard required. Analysis of the results shows that cosmetic on the market which is face cream and soap are contains of mercury with limit of concentration in percent level.
\end{abstract}

Key words : Mercury, Cosmetic, Verification.

\section{PENDAHULUAN}

Kosmetika adalah bahan atau campuran bahan untuk digosokkan, dilekatkan, dituangkan, dipercikkan atau disemprotkan pada, dimasukkan dalam, dipergunakan pada badan atau bagian badan manusia dengan maksud untuk membersihkan, memelihara, menambah daya tarik atau mengubah rupa dan tidak termasuk golongan obat (Permenkes 220/1976).

Kosmetika menjadi salah satu bagian yang sulit dipisahkan dengan manusia terutama wanita. Meningkatnya pendapatan seseorang akan meningkatkan kepedulian seseorang terhadap penampilannya. Penampilan yang mayoritas disukai oleh wanita adalah kulit yang mulus dan bersih bahkan sebagian besar menyukai kulitnya menjadi lebih putih. Oleh karena itu banyak produk kosmetika yang beredar, menjanjikan kulit lebih cerah dan putih, bahkan Badan Pengawas Obat dan Makanan (BPOM) sering mengadakan razia dan penarikan terhadap kosmetika ilegal yang beredar di masyarakat yang ternyata mengandung raksa/mercury $(\mathrm{Hg})$.

Peraturan Menteri Kesehatan No.445/ Menkes/Per/V/1998 menginstruksikan untuk melarang penggunaan merkuri pada kosmetika 
dengan bentuk sediaan krim pemutih, beda kompak, sabun, pearl cream. Akan tetapi peraturan ini tidak didukung dengan Standar Nasional Indonesia (SNI) yang hanya melarang penggunaan merkuri pada krim pemutih kulit (SNI 16-4954-1998), sedangkan pada kosmetika lain tidak diatur mengenai pelarangan penggunaan merkuri. Cara uji merkuri yang disebutkan hanya cara uji secara kualitatif dengan metode uji yang telah divalidasi, dengan demikian tidak ada metode yang valid dan seragam yang digunakan oleh analis untuk mengklaim bahwa kosmetik tertentu positif mengandung merkuri dengan konsentrasi yang diketahui nilainya, karena serendah apapun konsentrasi merkuri dalam kosmetik tidak diperbolehkan.

Berdasarkan hal tersebut diatas, perlunya dilakukan verifikasi dengan menggunakan metode harmonisasi ASEAN dengan nomor dokumen ACM THA 05. Adapun metode ini sebenarnya telah disepakati sejak 2004 dengan melalui beberapa kali modifikasi akhirnya disetujui dan ditetapkan pada bulan Juli 2006.

\section{BAHAN DAN METODE}

Bahan dan metode yang digunakan berdasarkan Standar ASEAN dengan nomor dokumen ACM THA 05 revisi 1, pertanggal 12 Juli 2006 dengan judul "Determination of Heavy Metals (Arsenic, Cadmium, Lead, and Mercury) in Cosmetic Products".

\section{Bahan}

Semua bahan kimia yang digunakan merupakan grade pro analisis, antara lain : asam nitrat, $1,1 \%$ timah (II) klorida/SnCl 2 dalam $3 \%$ asam klorida $(\mathrm{HCl}), 0,2 \%$ sodium borohidrat dalam $0,05 \%$ sodium hidroksida, air dengan resistivitas $\geq 18,2 \mathrm{M} \Omega$, larutan standar mercury $(\mathrm{Hg})$ yang tertelusur ke NIST dengan deret 0,5 ; 1 ; 2 ; 3 ; dan $5 \mu \mathrm{g} / \mathrm{L}$ dalam $3 \%$ volume/volume asam hidroklorida.

Peralatan yang digunakan antara lain : penangas air, labu digesi $50 \mathrm{~mL}$, pendingin tegak, kertas saring Whatman No.40, lampu katoda berongga $\mathrm{Hg}$ dan Lab. Analyzer 254, Mercury Instrumen yang memakai sistem uji injeksi (uap dingin) pada panjang gelombang 235,7 $\mathrm{nm}$.

\section{Metode}

Prinsip metode ini adalah zat organik di dalam contoh uji dihancurkan dengan digesi basah dan penentuan kandungan raksa $(\mathrm{Hg})$ dalam contoh uji dengan menggunakan sistem uji injeksi mengalir pada suhu ruangan pada panjang gelombang 235,7 nm. Metode persiapan contoh yang digunakan yaitu destruksi basah dengan cara kerja sebagai berikut yaitu dengan terlebih dahulu menyiapkan blanko bahan kimia tanpa menambahkan contoh uji dan diperlakukan sama seperti perlakuan terhadap contoh uji.

Untuk contoh kosmetik ditimbang dengan seksama 0,5 gram contoh kedalam erlenmeyer tutup asah dan menambahkan $7 \mathrm{~mL}$ asam nitrat kemudian memanaskan larutan contoh diatas penangas bersuhu maksimum $60^{\circ} \mathrm{C}$ sekurangkurangnya 3 jam. Setelah itu larutan didinginkan dan ditambahkan dengan $50 \mathrm{~mL}$ air. Kemudian contoh didiamkan selama 24 jam dalam lemari pendingin untuk contoh krim dan lipstik. Kemudian dilakukan penyaringan dengan kertas saring Whatman No.40.

Larutan yang telah didigesti tersebut diatas kemudian dianalisa menggunakan teknik uap dingin (cold vapour mercury technique) dengan peralatan mercury analyzer. Dengan terlebih dahulu membuat deret larutan standar dengan konsentrasi 0,$5 ; 1,0 ; 2,0 ; 3,0 ; 4,0$; dan $5,0 \mu \mathrm{g} / \mathrm{L}$. Setelah deret standar siap kemudian deret standar, blanko dan larutan contoh uji diukur absorbansinya.

Larutan deret standar yang telah dibaca absorbansinya, dibuat kurvanya dengan memplot respons absorbansi terhadap konsentrasi dalam $\mu \mathrm{g} / \mathrm{L}$ kemudian memasukkan absorbansi larutan contoh terhadap persamaan linier yang didapat sehingga diperoleh konsentrasi contoh uji dalam $\mu \mathrm{g} / \mathrm{L}$. Selanjutnya konsentrasi contoh dalam satuan berat per berat mengikuti persamaan sebagai berikut :

Konsentrasi $\mathrm{Hg}=$ konsentrasi larutan $(\mu \mathrm{g} / \mathrm{L}) \times \mathrm{fp} \times$ vol larutan $(\mathrm{ml})$ $(\mu \mathrm{g} / \mathrm{g}) \quad \frac{\mathrm{g}}{\text { bobot contoh }(\mathrm{g}) \times 1000}$

\section{HASIL DAN PEMBAHASAN}

\section{Verifikasi}

Verifikasi yang dilakukan terhadap contoh bedak dengan ulangan sebanyak 3 kali dan parameter yang diamati adalah presisi, akurasi, linieritas, dan limit deteksi yang akan dibandingkan dengan batas yang telah ditetapkan pada metode standar tersebut. Adapun batasan nilai yang telah ditetapkan dalam standar tersebut dapat dilihat pada Tabel 1.

Hal pertama yang dilakukan adalah analisa terhadap contoh bedak tanpa diperkaya dengan analit atau selanjutnya disebut contoh tanpa spike. Informasi dari contoh tanpa spike ini adalah untuk mengetahui apakah bedak yang akan dilakukan verifikasi mengandung analit $\mathrm{Hg}$ 
atau tidak. Dapat dilihat dari Tabel 2 bahwa bedak mengandung $\mathrm{Hg}$ sebesar $0,72 \mu \mathrm{g} / \mathrm{L}$, nilai ini tidak dapat diabaikan karena untuk menentukan \% perolehan kembali dari analit yang ditambahkan (\% recovery).

Tabel 1. Nilai untuk validasi metode berdasarkan pada Metode ACM THA 05

\begin{tabular}{ccccc}
\hline Parameter & $\begin{array}{c}\text { Nilai yang } \\
\text { diamati }\end{array}$ & Batasan & Satuan & Ket. \\
\hline Presisi & $\begin{array}{c}\% \text { Relative } \\
\text { standard } \\
\text { deviation }\end{array}$ & $<15$ & $\%$ & $\begin{array}{c}\text { Kandung-an } \\
\mathrm{Hg}: 1 \mu \mathrm{g} / \mathrm{g}\end{array}$ \\
Akurasi & $\%$ recovery & $\begin{array}{c}95 \\
\text { sampai } \\
108\end{array}$ & $\%$ & \\
Linearitas & $\begin{array}{c}\text { Koefisien } \\
\text { korelasi, } \mathrm{r}\end{array}$ & $>0,99815$ & - & $\begin{array}{c}\text { Range 0,5 } \\
\text { sampai } 5,0 \\
\mu \mathrm{g} / \mathrm{L}\end{array}$ \\
Limit deteksi & \multicolumn{2}{c}{0,5} & $\mu \mathrm{\mu g} / \mathrm{g}$ & \\
\hline Sumber: ACM THA 05 revisi 1, pertanggal 12 Juli 2006
\end{tabular}

Pada penelitian ini dilakukan 2 kali tahapan yaitu yang pertama contoh bedak diperkaya dengan analit $\mathrm{Hg}$ untuk menentukan nilai dari parameter presisi dan akurasi, sedangkan tahapan kedua yaitu hanya menganalisa contoh bedak tanpa penambahan analit $\mathrm{Hg}$ untuk mengetahui nilai dari deteksi limit. Karena itu akan dimiliki 2 buah kurva kalibrasi yang akan mempunyai 2 nilai dari linearitas.

\section{Presisi}

Presisi ditentukan melalui metode replikasi pengujian yang bertujuan untuk melihat konsistensi hasil, kesesuain metode pengujian dengan contoh uji serta kestabilan peralatan ukur/instrumen (Anwar hadi 2005). Penentuan presisi yaitu dengan mencari nilai dari relative standard deviation dari 7 kali perlakuan ulangan, yaitu membagi nilai standar deviasi dengan rerata dan kemudian dikalikan dengan $100 \%$ (AOAC Guidelines 2002).

Dari Tabel 2 terlihat bahwa nilai presisi yang didapat adalah $1,38 \%$ dimana nilai ini jauh dibawah ambang batas yang ditetapkan yaitu 15\% (Tabel 1).

\section{Akurasi}

Akurasi adalah kedekatan suatu hasil pengujian atau rerata hasil pengujian ke nilai yang sebenarnya (Anwar Hadi 2005). Untuk akurasi/ketepatan dari pengujian yang dilakukan yaitu dengan mencari persentasi perolehan kembali (recovery) dari konsentrasi spike yang sengaja ditambahkan pada 7 kali ulangan. Nilai rerata dari persen recovery dari analisa bedak didapat $107,7 \%$ (Tabel 3) dimana nilai ini masuk dalam range yang dipersyaratkan standar yaitu 95 sampai 108\% (Tabel 1).

Tabel 2. Data analisis uji $\mathrm{Hg}$ presisi pada contoh bedak

\begin{tabular}{ccc}
\hline Ulangan & Absorbansi & Konsentrasi $(\mu \mathrm{g} / \mathrm{L})$ \\
\hline Contoh tanpa spike & 0,0216 & 0,72 \\
1 & 0,0622 & 2,93 \\
2 & 0,0613 & 2,88 \\
3 & 0,0617 & 2,89 \\
4 & 0,0602 & 2,82 \\
5 & 0,0617 & 2,91 \\
6 & 0,0607 & 2,85 \\
7 & 0,0607 & 2,84 \\
\hline Rerata & 0,0612 & 2,8743 \\
\hline SD & 0,0007 & 0,0395 \\
\hline RSD (\%) & & $1,38 \%$ \\
\hline
\end{tabular}

Tabel 3. Data analisis uji akurasi Hg dalam contoh bedak

\begin{tabular}{cccc}
\hline $\begin{array}{c}\text { Konsentrasi } \\
+ \text { spike } \\
(\mu \mathrm{g} / \mathrm{L})\end{array}$ & $\begin{array}{c}\text { Konsentrasi } \\
\text { non spike } \\
(\mu \mathrm{g} / \mathrm{L})\end{array}$ & $\begin{array}{c}\text { Konsentrasi } \\
(\mu \mathrm{g} / \mathrm{L})\end{array}$ & \% Recovery \\
\hline 2,93 & 0,72 & 2,21 & 110,5 \\
2,88 & 0,72 & 2,16 & 108 \\
2,89 & 0,72 & 2,17 & 108,5 \\
2,82 & 0,72 & 2,10 & 105 \\
2,91 & 0,72 & 2,19 & 109,5 \\
2,85 & 0,72 & 2,13 & 106,5 \\
2,84 & 0,72 & 2,12 & 106 \\
\hline \multicolumn{4}{c}{ Rerata } \\
\end{tabular}

\section{Linearitas}

Nilai linearitas didapat dengan mencari nilai regresi dari persamaan garis linear yang diperoleh dari data kalibrasi larutan standar $\mathrm{Hg}$. Pada penelitian kali ini didapat nilai linearitas yaitu 0,99972 (Tabel 4) untuk penentuan uji presisi-akurasi dan 0,99889 (Tabel 5) untuk penentuan uji parameter limit deteksi. Kedua nilai tersebut berada diatas nilai yang ditetapkan yaitu 0,99815 (Tabel 1 ). 
Tabel 4. Data kalibrasi larutan standar Hg penetapan uji presisi dan akurasi

\begin{tabular}{cc}
\hline Standar & Absorbansi \\
\hline 0,5 & 0,0167 \\
1,0 & 0,0276 \\
2,0 & 0,0456 \\
3,0 & 0,0638 \\
4,0 & 0,0808 \\
5,0 & 0,1004 \\
\hline
\end{tabular}

Persamaan garis linier :

$$
y=a+b x
$$

$Y=0,0183 x+0,0085$

$\mathrm{R}=0,99972$

Tabel 5. Data kalibrasi larutan standar $\mathrm{Hg}$ penetapan limit deteksi metode (LDM)

\begin{tabular}{cc}
\hline Standar & Absorbansi \\
\hline 0,5 & 0,0114 \\
1,0 & 0,0170 \\
2,0 & 0,0324 \\
3,0 & 0,0496 \\
4,0 & 0,0654 \\
\hline
\end{tabular}

Persamaan garis linear

$y=a+b x$

$Y=0,01570 x+0.00218$

$\mathrm{R}=0,99889$

\section{Limit Deteksi}

Limit deteksi adalah konsentrasi terkecil dari analit yang masih dapat diestimasi dengan nilai yang dapat diterima, penentuan nilai limit deteksi yaitu dengan menjumlahkan blanko bahan kimia dengan 3 kali standar deviasi dari 7 kali ulangan contoh (AOAC Guideline 2002). Pada Tabel 6 terlihat bahwa limit deteksi metode ini adalah $0,405 \mu \mathrm{g} / \mathrm{l}$, dengan bobot contoh 0,5 gram yang dilarutkan dalam $50 \mathrm{~mL}$ sehingga limit deteksi metode (LDM) adalah 0,0405 $\mu \mathrm{g} / \mathrm{g}$.

\section{Hasil Analisa Kandungan Merkuri Dalam Contoh Kosmetika}

Setelah dipastikan bahwa metode uji tersebut stabil selanjutnya dilakukan analisa terhadap contoh kosmetika yang disampling di pasaran dan salon kecantikan dengan metode tersebut. Contoh kosmetika didapat dari konsumen yang secara sadar mengujikan kosmetika yang digunakannya untuk dianalisa keamanan kosmetiknya dan sebagian lagi berasal dari teman di lingkungan kantor yang kesemuanya merupakan kosmetika racikan yang didapat dari para medis dan klinik kecantikan. Adapun hasil analisa kandungan $\mathrm{Hg}$ dari beberapa kosmetika tersebut dapat dilihat dari Tabel 7 dengan tidak menyebutkan para medis atau klinik kecantikan yang meraciknya.

Hasil penelitian pada Tabel 7 menunjukkan, kandungan merkuri dalam kosmetik sangat mencengangkan karena kandungan merkuri bukan berada dalam level bagian per juta (part per million/ppm) tetapi berada dalam level konsentrasi persen, hal ini jauh diatas ambang batas maksimum yang ditetapkan oleh Badan Kesehatan Dunia (WHO) sebesar 0,5 ppm yang ditujukan untuk pengobatan penyakit tertentu dibawah pengawasan dokter ahli.

Dari Tabel 7 terlihat hanya sabun muka yang mengandung merkuri dalam konsentrasi ppm sedangkan semua krim yang melekat pada wajah berjam-jam mengandung merkuri dalam level konsentrasi persen. Tidak dapat dibayangkan andaikan terus menerus digunakan maka merkuri akan masuk ke dalam jaringan darah dan tubuh kita yang akan berakibat panjang dan fatal. Efek jangka pendek sebenarnya dapat dirasakan oleh pengguna, yaitu apabila penggunaan krim dihentikan maka akan menimbulkan bercak-bercak hitam pada kulit yang akhirnya bukan mempercantik melainkan memperburuk kulit.

Tabel 6. Pengamatan konsentrasi penentuan limit deteksi metode (LDM)

\begin{tabular}{ccc}
\hline Ulangan & Absorbansi & $\begin{array}{c}\text { Konsentrasi } \\
(\mu \mathrm{g} / \mathrm{L})\end{array}$ \\
\hline 1 & 0,0297 & 1,75 \\
2 & 0,0252 & 1,47 \\
3 & 0,0226 & 1,30 \\
4 & 0,0252 & 1,47 \\
5 & 0,0243 & 1,41 \\
6 & 0,0257 & 1,50 \\
7 & 0,0283 & 1,66 \\
8 & 0,0278 & 1,64 \\
9 & 0,0278 & 1,63 \\
\hline Rerata & 0,0260 & 1,5157 \\
SD & 0,0021 & 0,1350 \\
LDM & 0,4049 & 0,4050 \\
LDM $(\mu g / g)$ & 0,0405 & 0,0405 \\
\hline
\end{tabular}


Tabel 7. Hasil analisa kandungan $\mathrm{Hg}$ dalam kosmetik

\begin{tabular}{|c|c|c|c|c|c|c|c|}
\hline Tgl & Kode contoh & $\begin{array}{l}\text { Bobot } \\
\text { (g) }\end{array}$ & $\begin{array}{l}\text { Volume } \\
\quad(\mathrm{mL})\end{array}$ & Absorbansi & $\begin{array}{l}\text { Kons } \\
(\mu \mathrm{g} / \mathrm{L})\end{array}$ & $\begin{array}{c}\text { Faktor } \\
\text { pengen- } \\
\text { ceran }\end{array}$ & $\begin{array}{c}\text { Konst. } \\
(\%)\end{array}$ \\
\hline \multirow[t]{2}{*}{12 Maret 2010} & 0068/KA/10 & 0,5037 & 50 & 0,0554 & $56.501,8$ & 50 & 0,56 \\
\hline & 0069/KA/10 & 0,5208 & 50 & 0,1332 & 169.951 & 50 & 1,63 \\
\hline \multirow[t]{2}{*}{23 Maret 2010} & 0089/KA/10 & 0,5541 & 50 & 0,1054 & $46.509,3$ & 20 & 0,42 \\
\hline & 0090/KA/10 & 0,5808 & 50 & 0,1845 & $41.460,3$ & 10 & 0,36 \\
\hline \multirow{4}{*}{$\begin{array}{l}10 \\
2010\end{array}$} & 0317/KA/10 & 0,5629 & 50 & 0,0864 & 221.326 & 62,5 & 1,96 \\
\hline & 0318/KA/10 & 0,5440 & 50 & 0,0745 & 190.496 & 62.5 & 1,75 \\
\hline & 0319/KA/10 & 0,5724 & 50 & 0,1153 & 296,161 & 62,5 & 2,59 \\
\hline & 0320/KA/10 & 0,5163 & 50 & 0,0555 & 5648,1 & 25 & 0,055 \\
\hline \multirow[t]{6}{*}{2 Agustus 2011} & A (cream siang $<40$ thn) & 0,5071 & 50 & 0,0473 & 190701 & 62500 & 1,88 \\
\hline & B (cream malam $<40$ thn) & 0,5547 & 50 & 0,0654 & 262939 & 62500 & 2,37 \\
\hline & $C$ (cream siang $>40$ thn $)$ & 0,5081 & 50 & 0,0786 & 315402 & 62500 & 3,10 \\
\hline & $\mathrm{D}$ (cream malam $>40$ thn $)$ & 0,5466 & 50 & 0,0670 & 269181 & 62500 & 2,46 \\
\hline & E (sabun muka) & 0,5136 & 50 & 0,0184 & 60,63 & 50 & $5,9 \mathrm{mg} / \mathrm{kg}$ \\
\hline & $\mathrm{F}($ krim malam) & 0,5213 & 50 & 0,0455 & 183590 & 62500 & 1,75 \\
\hline
\end{tabular}

\section{Efek Merkuri terhadap Kesehatan}

Berdasarkan temuan Diner dan Brenner (1998) serta Frackelton dan Christensen (1998) dikatakan bahwa diagnosa klinis keracunan $\mathrm{Hg}$ tidaklah mudah dan sering dikaburkan dengan diagnosa kelainan psikiatrik dan autisme. Kesukaran diagnosa tersebut disebabkan oleh karena panjangnya periode laten dari mulai terpapar sampai timbulnya gejala dan tidak jelasnya bentuk gejala yang timbul, yang mirip dengan kelainan psikiatrik. Paparan oleh $\mathrm{Hg}$ (biasanya berupa metil merkuri) pada saat prenatal akan nampak setelah bayi lahir yang dapat berupa cerebral palsy maupun retardasi mental. Keracunan $\mathrm{Hg}$ yang akut dapat menyebabkan terjadinya kerusakan saluran pencernaan, gangguan kardiova sculer, kegagalan ginjal akut maupun shock. Pada pemeriksaan laboratorium tampak terjadinya denaturasi protein enzim yang tidak aktif dan kerusakan membran sel (Sudarmaji dkk).

\section{KESIMPULAN}

Metoda ACM THA 05 revisi 1, pertanggal 12 Juli 2006 dengan judul "Determination of Heavy Metals (Arsenic, Cadmium, Lead, and Mercury) in Cosmetic Products" dapat dipergunakan untuk menganalisa merkuri dalam kosmetik dengan memperhatikan parameter validasi antara lain presisi, akurasi, linearitas, dan deteksi limit menghasilkan nilai yang memenuhi batasan yang dipersyaratkan dalam standar tersebut.
Merkuri tidak diperbolehkan dengan konsentrasi berapapun di kosmetik, akan tetapi pada kenyataannya didapat merkuri dalam level persen yaitu kisaran 0,6 sampai $3,1 \%$ di dalam krim hasil racikan dari pihak medis, salon, dan klinik kecantikan yang berasal dari contoh produk krim dan sabun yang ada di pasaran. Hal ini merupakan peringatan untuk memperhatikan semua kosmetik yang beredar di masyarakat dengan memperkuat peraturan dan standar yang dapat dijadikan acuan seragam untuk menentukan kadar merkuri dalam kosmetik.

\section{DAFTAR PUSTAKA}

ASEAN Standard. 2006. ACM THA 05 revisi 1 "Determination of Heavy Metals (Arsenic, Cadmium, Lead and Mercury) in Cosmetic Products".

AOAC Guidelines. 2002. Guidelines for Single Laboratory Validation of Chemical Methods for Dietary Supplements and Botanicals.

Badan Standardisasi Nasional. 1996. SNI 164380-1996 Pembersih kulit muka. Jakarta: BSN.

Badan Standardisasi Nasional. 1996. SNI 164399-1996 Sediaan tabir surya. Jakarta: BSN.

Badan Standardisasi Nasional. 1998. SNI 164954-1998 Krim pemutih kulit (Bleaching cream). Jakarta: BSN.

Hadi, Anwar. 2005. Konsep Dasar Pengendalian Mutu Laboratorium Pengujian. Jakarta: Pusarpedal Kementerian Lingkungan Hidup. 
Kementerian Kesehatan. 1998. Peraturan Menteri Kesehatan No.445/Menkes/ Per/V/1998, Bahan kimia yang dilarang pada kosmetik. Jakarta: Kemenkes.

Sudarmaji, dkk, 2006. Toksikologi Logam Berat B3 Dan Dampaknya Terhadap Kesehatan Lingkungan, vol.2, No. 2 Januari 2006 : 129-142, FKM Universitas Airlangga. 